\title{
The Third World Option in a Globalized Building Materials Market: The Nigeria Case Study \\ *Atolagbe, A.M.O.
}

\begin{abstract}
Globalization has been described as a world phenomenon that provides a level ground for competitive rivalry between economies, skills, goods, technological and industrial products, etc, from every part of the global World-More Developed Countries (MDC) and Less Developed Countries (LDC) alike. In this study, the extent to which the ground is "level" for globalization is examined between the more and less developed nations of the world, using Nigeria as a study case for the latter. The study examines the relationship of globalization to the level of industrial and economic development of nations in general, and specifically, the industrial and economic status of Nigeria in the committee of nations. The study notes the wide disparity in the level of industrialization and economic development between the more and less developed countries of the world. Drawing from history and experience and enlisting certain social economic and environmental theories relevant to the industrial and economic development of nations the study concludes and makes a case against third world nations from procuring building materials from a globalized market. Further, the study suggests the enactment of state policy measures and interventions capable of protecting native industries and production technology from the choking influences of those from industrially, more developed, nations of the world.
\end{abstract}

\section{Introduction}

ne current phenomenon that has
been evoked for the convergence of the world economies- trade, technology, merchandise, etc - is globalization. It has been described as a process of creating a world market such that goods, investments, trade and information are integrated (Mayaki, 2003).

Globalization provides opportunity for a business enterprise, manufacture, etc, to link up and grow (or sink) in accordance to its status in quality, popularity, demand etc. - in a committee of businesses and investments. In other words, the market provides (or is supposed to provide) a level ground for competitive rivalry between economies, skills, technological and industrial products from every part of the world.

Globalization is not without its merits. First, it offers an all-time shopping opportunity for all nations, rich and poor, on the basis of 'cash-and-carry' or ability to pay. Second, the market opens an entrance for, and attracts an unimaginable size of customers to competitive products and prices through advertisement and communication, both of which are also attributes of globalization. In other words the market provides a common ground to buy, and put out for sale, without discrimination or favour.

But is this what fairness entails in the world economy comprising of nations at different levels of development; where the First, Second and Third Worlds co-exist at different stages of economic, technological and industrial developments? Is the market a level ground where a few nations have most to sell and the majority only goes to buy?

The third world countries, mostly from Africa and Asia, have a few things in common; that puts them at a disadvantage in an open, economic, technological and industrial market with others from the First and Second worlds, notably Europe and America. Most of them (the former) have been colonies under current world economic and industrial giants; and under such colonial rules have had their native technological culture (including those in the building materials industry) scuttled by the domineering influences and processes of their colonial masters. Nigeria for instance, was, for about a century under the British Rule. During this period, the trend and process of their technological growth suffered under the 'superior' influence of their colonial masters. By 1960, when Nigeria assumed a level of political and economic independence from Britain, virtually all the indigenous methods of production and manufacture had either been jettisoned or derided in preference to foreign or imported techniques. Till date, a reorientation towards indigenous values has not been achieved with any remarkable success among citizens whose native values have been selfdebased, considered inferior and unacceptable. The state of technological and industrial casualty of the less developed countries is a resultant effect of the colonial experience.

First, and specifically in building materials production, these third world nations failed to build on the techniques that satisfied the needs of their fore fathers; which was 
clearly and procedurally handed over to them. Before proceeding to give the second effect of the colonial experience of these third world nations, it is important to examine the place of building materials in the acquisition of decent housing facilities; especially among these nations. Building materials are generally believed to constitute between $40-80 \%$ of the total input of building construction (Ifesanya 2007). Its input into low cost housing - which constitutes the bulk of Third World housing need, is even considered higher. Thus, the production and use of building materials is not only relevant in housing (and other buildings) development and management, but to the economic, social, cultural and environmental sustainability of these nations. The second casualty resulting from the colonial experience is that the colonised could not grapple with the new foreign-based technology that was introduced to them mid-way by the colonialists. Third, the colonialists left at independence, when citizens were at a crossroad: they had abandoned what they had and knew; and had not come to grips with, what they liked; the new technology. Most of the third world countries are today still in a technology dilemma- to go back to their indigenous methods which trend has created a yearning gap or continue with so-called modern techniques they know helplessly little about?. This is the technological dilemma that these nations and their governments have landed since independence. In the circumstance, what technological or industrial products can these nations be expected to bring into the global market?

Nigeria Industrialization and Globalization

For the purpose of determining the implications of the world market (or globalization) on production of domestic building materials, specifically, in Nigeria, it is pertinent to acknowledge to which side of the divide Nigeria belongs: what is Nigeria's status, as a third world country in world industrialization and building materials technology?

Nigeria's economy, and to a large extent, its lifestyle, is "import" based! Except for crude oil and a few plant produce (e.g. cocoa, rubber, etc.) that constitute a small percentage of Nigerian export commodities and whose annual production has fallen constantly since the late $80 \mathrm{~s}$, the vast majority of its needs are imported. These include religion, dresses, automobiles, industrial, educational and agricultural machineries, etc. It is thus obvious, that in the globalized market, Nigeria like its third world counterparts will remain a perpetual buyer. But has Nigeria the financial resources to sustain this role? The dwindling trend in per capital income and the falling exchange rate of the naira until in recent time is informative to the contrary (Adedeji 2003). The history of Nigerian housing and various interventions by governments and the private sector to achieve sufficiency is also replete with, among other measures, massive importation of building materials like cement (Arayela 2000); cement and timber products, refractory materials, tiles, glass, aluminum, steel, cables, plastics, ceramic products, etc. (Okpala 1985). How did Nigeria, like other African nations, and indeed the third world become so dependent?

Much of this could be traced to the social, economic, political, etc re-orientation, courtesy of the wave of colonization. This could be glimpsed from the study of building materials trend from pre-colonial period till date. This trend, which could be referred to as the "Building Materials Transition" in Nigeria is, here reviewed to provide a framework for tracking the trajectory of changes in building materials preference in Nigeria from precolonial period till date.

\section{Building Materials (and Other Values) Transition Process}

This theory is enlisted in tracing, not only the gradual change from the era of dominant use of indigenous building materials to the era of widespread use of conventional materials, but also in explaining the underlying factors. In order to understand the complex mechanism involved, this change in the Nigeria housing history can be discussed under three epochs: the pre-colonial (or indigenous pre-1814), the colonial (1814-1960), post independence (1960 till date). The post independence epoch can be divided into three phases based on the economic prosperity of the country. In the first phase (1960-1970) the country subsisted on agriculture. In the second phase (19970-1975) often considered a period of oil boom, the country subsisted on oil revenue while in the third phase (1975 till date) the country has witnessed a period of economic recession due to over dependence on oil revenue and the global oil glut of the eighties. Each of these periods is distinguished 
by distinctive socio-economic and technological characteristics.

The pre-colonial era witnessed a steady growth in the indigenous housing methods in Nigeria. Needless to say, the indigenous housing method thrived predominantly on indigenous building materials, technology and styles prevalent in each of the over two hundred and fifty nationstates and over five hundred ethnic and linguistic groups in Nigeria (Oluyode 1988; Saad and Ogunsusi 1996). It was an indigenous era and each of these groups and nation states was socio-culturally homogenous. Each depended on and drew from a common range of construction materials that, according to Adetona (1986) and Kalilu (1997) included mud, stone, wood, grass, hides \& skins, bamboo among others. Each of the communities was self-contained, deriving all its housing resources like materials, human, technology and technical know how from the immediate environment. The materials, the technology and the communal building process were intimately knitted with the climatic requirement, socio-economic and cultural values of the community in each environment.

Consequently, every family who needed a house owned one, as the contribution of kinsmen through social housing enhanced affordability. Varieties could be seen in form and styles. Yet similarities were observable in the use of materials and introduction of key functional spaces like the courtyard, the halls and general space hierarchy-a phenomenon Saad and Ogunsusi (1996) describe as 'Unity in Diversity'. Family sizes, royal or title statuses were reflected through the size of compounds and decorative carvings rather than any remarkable differences in building materials. This trend continued until towards $19^{\text {th }}$ century (1840s) when Brazilian style of Architecture entered the costal areas of Nigeria (Lagos) through slave returnees (PrucnalOgunsote 2001).

The colonial era, 1814-1960, marked the period of European, especially, British incursion into Nigerian political and thus, social, economic and cultural lifestyles. By 1920s, European influence had begun to be felt in the social, economic and cultural disposition of Nigerians. The building materials transition had begun. The traditional materials of construction, which had been of indigenous stock started to give way, gradually how-be-it, to imported materials (Fadahunsi 1985, Adeniyi 1985). The living pattern and styles including building forms, materials, methods and techniques of construction of the colonial masters became the envy of Nigerians, and virtually all aspirations were towards adopting these values.

At about this time government intervention in housing also started. For instance, in 1928, the first step in public housing and Town Planning commenced in Lagos following the bubonic plague that ravaged Lagos between 1925 and 1928 (Abiodun 1985: 51, Atolagbe 1997). The Lagos Executive Development Board was inaugurated for the purpose of resettling the affected people and planning and developing Lagos; thus signaling the process of Europeanoriented public housing, planning and building materials preference in Nigeria. Prior to, and of course long after this period, government involvement in housing had been in the form of residential quarters for the European senior government workers-the Government Reservation Areas, popular as G.R.As. These were generally fashioned (in styles, forms and materials) after the colonial interests and socio-cultural life patterns.

At the Post-Colonial or Post Independence Era, the transition rate became faster. The Nigerian senior government workers took over the G.R.As and perpetrated the policy of G.R.As. More and more Nigerians abandoned their indigenous values for imported ones. This was not only in housing and building construction, but also, in politics, governance, administration dressing and most other socio-cultural concerns.

\section{Influence of Western Education}

Our exposure to western education aided the transition better than any other factor. The first set of Architects and a great number of related professionals (in the building industry) studied in Europe, (especially Britain) and America. Most of these graduates became members of their respective foreign professional bodies (e.g. The Royal Institute of British Architects (RIBA) for Architects. Returnees from these foreign Universities, who were members of these foreign-based professional bodies, could not reasonably be expected to practise using tools (building materials and techniques) other than the ones they learnt and practised at their foreign bases. 
The same background education is accountable for the spread and perpetration of this change down, through generations of Nigerian graduates (in the building profession) and their practice orientation. Those of them who went into academics (teaching and research), back in Nigeria, did not only teach what they had acquired from their foreign universities, but fashioned their teaching curricula and research programs based on their background education. Not until recently was a serious attempt at research into domestic building materials started. Research works along these materials are not only far between; their acceptance by residents is also still too minimal for the desired change.

\section{Influence of Oil Wealth}

The period of oil boom, the 1970s, often considered the period of Nigerians national affluence, witnessed a most remarkable drift by Nigeria (as a nation) and its citizens, away from the Nigerian identity. In spite of the show of self-discovery in the hosting of the Festival of African Arts and Culture (FESTAAC) and the All African Games within this decade, Nigerians and their governments imported all manners of foreignbased ideas and materials. This included such things as eggs, wedding cakes, bottled water, chilled meat, hair (various colours of wigs), timber, etc. in preference to home-based ones (even where they were available). The sociocultural bias increased, generally, against what is Nigerian

The house and its components are a more permanent property than cars, clothing and food. Thus the evidence of changes in the former remains more permanent in the country's cityscape. Consequent upon this social migration, cities whose townscapes were dominated by indigenous building stocks in the 1920 s are today overwhelmingly surrounded by 'modern' structures leaving only the precolonial city cores with evidence of indigenous characters. Even here (city cores), a lot of indigenous structures have been given 'modern' surfacing through sand/cement work.

Thus, the development and gradual improvement on domestic building materials in Nigeria was scuttled by intervention of British colonizers in 1814. Today, 194 years after this disorientation, Nigeria still operates an importdominated economy, failing in the will, to look inwards, in spite of its vast endowments in natural and human resources.

The transition from indigenous building materials to conventional, "modern" materials occurred subtly, by a process of socio-cultural re-orientation of Nigerians. This was aided by the perceived superior status of the colonial masters and their liberal methods of political administration and state policies. It should be possible to experiment on the reversal of this trend by employing a similar tool. The governments (with the building professionals in their ministries), the affluent and the political class are held socially and economically superior in the society. Any values accredited to and accepted by such socially esteemed and respected people may catch easily with the people and become a vogue in the society. Thus the participation of governments, accompanied by their policy directives towards the adoption of domestic building materials for housing may reverse the existing trends in favour of these (domestic) materials.

\section{The Prospects of Indigenous Methods}

The argument for a return to precolonial housing practices should not be construed as a return to primitive practices. If the house is a cultural phenomenon; a symbol of a people's socio-cultural heritage (Olotuah 1997); and an encapsulation and metaphor of life (Kalilu 1997), then a change to indigenous housing practices implies a change in life and living values-from the acquired to native socio-cultural values, to the users' home environment, for materials, methods, styles, etc.

Housing, nay, architecture in Nigeria is today at a cross road, a stage in a journey at which confusion sets in, enthusiasm wanes and further steps hold little prospects. Ogunsakin (1997) locates the housing situation in Nigeria at a bridge between two cultures. An American architect philosopher, Frank Lloyd Wright (1887-1959) would have described such architecture (not deriving or emanating from its immediate environment) severally as, architecture of "split culture, split identity, split personality, a protest against self, or as inorganic". The argument here is for a desirable change; a return to architecture and housing practices predicated on Nigeria, its environment, its people (through easy affordability), its socio-cultural values, etc. A 
call to old order in Nigerian architecture (including housing and building materials policy) is a call back to hope, prospects, selfdependence, adequate housing and national identity. This prospect loomed gradually from prehistoric to pre-colonial era in Nigeria before it was stifled by the incursion of colonial practices. A retrospective examination of this old brand of architectural practice shows that it was based, unconsciously how-be-it, on some modern $\left(19^{\text {th }}\right.$ century), philosophies. One of them is that of "Organic Architecture" by Frank Lloyd Wright (alluded to earlier), whose central principle holds that a building should develop from its immediate environment (Ogunniyi 1996). Nigerian, indeed, African pre-colonial buildings, like the Egyptians, Romans, Greeks, and modern "Organic" buildings derived wholly from their immediate surroundings.

Many other modern environmental, economic, social, cultural, etc theories attest to the philosophical foresight and superiority of this old order over so called modern or decently, international of free style of architecture that overtook Nigerian, and indeed the Third World brand of architecture. The adoption of two of such theories which are of course incompatible with urbanization aided with the development of present industrialized nations. They are the theories of "People and Environment Relations" and "Free Trade Versus Infant Industry / Trade Protection"

\section{Theory of people and environmental relations (PER)}

In the theory of 'People-Environment

Relations' three distinctive views are adequately reflected in contemporary literature. These are the 'Minimalist' 'Instrumental' and 'Spiritual' perspectives (International Association for the Study of People and their Physical Surroundings-IAPS 1988).

The Minimalist view, which was popular among designers and behavioral scientists, prior to mid 1960s, argued that physical environments had minimal or negligible influence on the behavior, health and well being of their users. A relevant, but advanced extension of this theory is the one by Maslow, (1962), referred to as the theory of Psychological Health and 'Self Actualization'. This theory, also reflecting the Minimalist stance towards the environment recognizes that the physical and social environment serves basic human needs for shelter and security (emphasis mine). The aspect of the 'Minimalist' view that professes negligible environmental influence on users' health and behavior has since been discarded. This is in the face of evidences that environmental pollution leads to health hazards; over population leads to epidemics and incidents of plagues and spread of contagion through pollution - of water, air and other components of the environment. This led to another theory called the 'Instrument' or 'Mean-to end' view. This theory views the physical environment as a means for achieving important behavioral and economic goals (emphasis mine). The 'Means-end' view pervades much of the recent research on strategic facilities planning, which is clearly reflected in the Functionalist and modern movements in Architecture.

The analyses of people environment relation through instrumental view measure the capacity of environments to promote behavioral and economic efficiency as well as enhance levels of occupants' comfort, safety and well-being. The general view on the instrumental theory, which we refer to, here, as the Theory of "Environmental Self Containment" is that the physical environment of a people constitutes a veritable instrument or tool for enhancing the shelter, comfort, security and economic efficiency of its users. In other words, through judicious manipulation of, and logical interaction with the environment, a people can attain the utmost degree of self-sufficiency; as the environment contains adequate resources to sustain its users.

Following from this theory, the Nigerian environment is deemed to contain adequate resources to sustain all the needs of its users including their shelter, security, comfort and economic needs. The intervention of the British government and its housing policy may have scuttled the process of selfactualization that was evident in the country. A return to this trend; to a housing practice based on the resources of the Nigerian environment may lead untimely to adequate, affordable and decent housing for each of Nigerian socioeconomic and ethno-cultural groups. This practice may be of future industrial and economic interests to the Nigerian nation-state.

\section{Free trade versus infant industry theory}

In addition to forging national identity through the use of building materials available in the immediate environment, the socio- 
economic benefit of improving on materials and technology that belong to the immediate environment includes high employment rate, and conservation of foreign exchange earnings.

The argument against a return to local Nigerian environment and its resources may be hinged on the freedom of individual citizens to choose from all available options in materials, forms, technology and styles in accordance with international free trade and human rights chatter. But the 'Free Trade' theory has been faulted by economic theorist as being detrimental to industrial and economic advancement of the less developed countries of the world. This argument is well articulated in the theory called 'Free Trade' versus 'State Protection' (Toyo 2001). The theory, sometimes called 'Free Trade versus Infant Industry' examines and prescribes appropriate trade options for the more developed and less developed industries/nations of the World.

Mercantilism or the state use of the market was popular in Europe throughout the late middle -ages (1100-1500AD). State directed all economic production and commerce towards expanding exports and limiting imports; as export surplus meant good foreign exchange. By 1776 (Toyo 2001), mercantilism as a trade practice became controversial. Adam Smith, an English man, then an intellectual spokesman of the early capitalist industrialists, advanced a powerful argument for free trade across the boarders and an end to monopoly in production and trade. Free trade, Smith argued, would lead to larger markets for industrial goods, greater division of labour and increased output. German economists however countered this argument, positing that free trade was natural for a worldadvanced industry like England's. A less developed country like Germany, needed protection for its younger industries. Otherwise, it could remain under-developed through free trade; because its products were not in position to compete with that of established suppliers like England. This latter argument is famous in economics as the 'Infant Industry' argument for state protection (Toyo 2001:4). Later, it was further argued that state protection was even more justified if the established producer was a monopolist, who practiced dumping or subsidized its products.

Nigerian housing industry has operated under Free Trade since the coming of the British colonial lords. Foreign building materials, technology and styles have freely entered the country at the detriment of indigenous ones, which are not in the least position to compete with the former. The development of indigenous housing industry has since been on hold, giving room to importation from, first Europe and later the international world under the Free Style or International Style of Architecture. While it lasts, the Free or International Style of Architecture has been to the advantage of Europe, America and other countries that are well advanced in manufacturing industry (including the production of building materials). Building materials from less developed nations like Nigeria and its third world economies cannot hope for serious advancement until they fall back to, and continue in the development process of their indigenous industry, including the building materials. As it is, now, indigenous building materials in Nigeria cannot be expected to stand in a free market against the conventional ones, which have been tested, proved and accepted internationally through the years. They must, like an infant industry, be propped up and enabled through some state protection policies in the interest of economic and industrial development of the nation.

\section{Conclusion}

It is not in contest that competition is good. It enhances friendly relations, added knowledge and skill, growth, development and all. Competition must however be organized on fair premises; in sports parlance, competitors must take off from a level ground. Otherwise the gains of competition can be overturned. Competitions based on unequal match could only result in the defeat, frustration, psychological disability, incapacitation or outright destruction and extermination of the weaker side.

With specific reference to the development of domestic building materials, the competition engendered by globalization is unequally matched in favour of industrially advanced countries or economies and against industrially and technologically backward nations of the third world. The former have highly developed building materials (together with building skills and techniques) that have flourished in the international market over the years, long before the concept of globalization and courtesy of colonization. Such products will not only dominate but also continue to 
expand to the disadvantage of products from less industrially developed communities. The latter have not "arrived" technologically; they have been abandoned as primitive, traditional methods and materials in preference for the former. Products from less developed industrial nations are yet to find neither inroads into, nor recognition in the world or global, building materials market. They are thus, not in position to compete with those from the industrially more developed worlds. Thus globalization will favor industrially advanced nations and further scuttle development in less developed ones.

Whereas globalization may be profitable and thus, be prescribed for highly industrialized nations whose goods and products have already found footing in the world markets, not so with poor industrial nations like Nigeria to which globalization may impact a stifling effect. Products of these poorly industrialized nations are, to say the least, scanty, considered inferior and discriminated against, even in their home markets. Such goods have not begun to make inroads into the global market, let alone survive the unequally matched competition with products from industrialized nations. Besides, they have nothing (not even their producer nations) to recommend them into a market already dominated by products from highly industrial nations, which are acclaimed superior and thus, well sought after.

The Nigerian and indeed third world economy should not subscribe to globalization or international market forces. Rather, an aggressive policy should be put in place through adequate legislation to encourage, not only domestic sourcing of building materials, but also, to ensure their protection and local consumption. One method of aiding this policy is for Nigerian governments to subsidize or finance outright, the production of these materials. Such efforts may not yield immediate economic gains to the nation, but have the potential to enhance adequate housing in future and thus, the welfare of Nigerians. The adoption, development, and further improvement on these materials may, in no distant future, usher Nigeria into a committee of industrialized nations.

Research institutes and universities should be motivated to embark on studies for the manufacture of and improvement on domestic building materials which are regarded as more eco-friendly, available and sustainable (Olateju 1989, 1993; Olayeni 2007). Scholars, groups and individuals, interested in research along this line should be given grant or scholarship to do so.

Japan's, Architecture, with its garden houses and China's, with its peculiarly collapsible and tatamin-module housing, are examples of environmental, cultural and economic-conscious architecture and production processes. It is no coincidence that these countries recently surged into the committee of industrialized nations. Nigeria and the rest of the Third World should take a clue. 


\section{References}

Abiodun J. (1985) "Housing Problems in Nigerian Cities" Housing in Nigeria PojuOnibokun (ed) NISER Ibadan Pp 49-64.

Adedeji D. (2003) "Globalization of Building Materials - a Neo-colonial Strategy for African Economy: A Study of the Nigerian First Storey Building in Badagry, A Building Materials Policy for Nigeria Proceedings of the Nigerian Institute of Architect Conference held in Abuja between $10^{\text {th }}$ and $13^{\text {th }}$ Dec. 2003.

Adeniyi E.O. (1985) "Housing in Nigeria National Development" Housing in Nigeria Poju Onibokun (ed) NISER Ibadan Pp 91-104 Arayela .O. (2002) "Development of Stabilized Laterite Bricks for Building CostReduction in South Western Nigeria". Unpublished Ph.D (Arch) Thesis Submitted to the Department of Architecture, School of Environmental Technology, Federal University of Technology, Akure.

Atolagbe A.M.O. (1997) "Affordable Shelter for the Urban Low-income Class in Nigeria: Local Resources Strategy" The House in Nigeria Bayo Amole (ed) Proceedings of a National Symposium at Obafemi Awolowo University Ile Ife.

Fadahunsi S.O. (1985) "Fifty Years of Housing in Nigeria" Housing in Nigeria. Poju Onibokun (ed) NISER Ibadan Pp 105-132.

Ifasanya, S.O. (2007), "Building/Materials Production and use" Housing Development and Management, Tunde Agbola, Layi Egunjobi and C.O. Olatubara (ed). Department of Urban \& Regional Planning, of Ibadan, Ibadan Nigeria Pp 310 - 349.

International Association for the Study of People and their Surroundings IAPS (1988)DELFT, The Netherlands July 5-8.
Mayaki. S. (2003) "Building Industry Requires Protection from Globalization"Symposium of the Construction / Engineering Service Group of the Lagos Chamber of Commerce and Industry. 'The Punch' Monday Oct. 27, P.43. Ogunniyi N.T. (1996) The Learning Era in Modern Architecture in Nigeria. Funky Press; Okpala D.C. (1985) "Housing and the Construction Industry in Nigeria" Housing inNigeria. Poju Onibokun (ed) NISER Ibadan Pp 251-263

Olateju Bayo (1989) Earth Construction

Technology for Housing Development Studies In Environmental Design for West Africa: vol. 8:91-97

Olateju B. (1993), The Structural performance of Bambusa Vulgaria Reinforced Terracrete Components in flexure The Professional Builders Journal: 30-39 .

Olayeni, K.P. (2007) "Eco-Design

consideration in sustainable Architecture"

Towards a Sustainable Built and Natural Environment Fadare, W. and Adesanya, A. (ed). Faculty of Environmental Design and Management Obtain Awolowo University IleIfe, Nigeria. Pp. 163-169.

Prucnal-Ogunsote B. (2001) "Classification of Nigerian Architecture" AARCHESJournal Vol. 1 No 6 September. Pp 48-56.

Saad, H.T. and Ogunsusi .V. (1996) Unity in Diversity, Continuity in Changes: The Traditional Architecture of Nigeria Colloquium for Nigerian Traditional Architecture: (HABITAT II), Istanbul, Turkey. June 3-14 